\title{
COCONUT NUTRITION IN PAPUA NEW GUINEA
}

\author{
By \\ Ollivier, J. ${ }^{1,2}$, Akus, W. ${ }^{2}$, X. Bonneau ${ }^{1}$
}

\begin{abstract}
Copra yield in Papua New Guinea is estimated at 0.6 tonnes per hectare per year. Several factors may be responsible for this low productivity compared to other Asia Pacific countries. Amongst these, nutrient deficiency is an important limiting factor. In order to evaluate coconut nutrition status in PNG, leaf sample collection was undertaken by examining 23 sites around the country and from a nutrition trial carried out at the Stewart Research Station of the PNG Cocoa \& Coconut Research Institute (PNG-CCRI) in the Madang Province. Results of leaf analysis revealed significant widespread nitrogen deficiencies at most of the sampled sites and geographic variations in potash deficiency. Chlorine deficiency varied with geographic sites and was closely related to the prevailing wind pattern. Preliminary results on nut-set and flowering in the trial at Stewart Research Station revealed a positive response to nitrogen and chlorine-based fertilizer applications. This suggests that appropriate fertilizer applications would be benefit future coconut production on this particular site.
\end{abstract}

\section{INTRODUCTION}

The coconut palm (Cocos nucifera L.) is cultivated extensively in 14 coastal and Island Provinces of Papua New Guinea (PNG). The land area under coconut palms is currently estimated to be about 250,000 hectares. Copra production in the recent past stabilized around 140,000-150,000 tonnes (APCC yearbook, 1997). For a considerable proportion of the coastal population, copra production provides an important source of cash income.

Depending largely on palm age and agro-ecological conditions, copra yield per hectare was estimated to vary from 0.5 to 1.0 tonne per hectare (t/ha), with an overall average of $0.6 \mathrm{t} / \mathrm{ha}$ which is quite low compared to other countries in the region. The problem of low productivity of coconut in PNG is caused by a number of factors such as: the use of unselected low yielding planting material, the high proportion of senile palms on plantations, insect pest problems which limit considerable hybrid coconut plant development in the Islands regions. Lack of incentive for farmers to maintain constant level of productivity, competition from other crops such as oil palm having a higher economic return which are substituted for the coconut palm and bad management practices and nutritional deficiencies are also factors limiting the productivity.

While breeding work and adoption of high yielding varieties from farmers are a very long term exercise, agronomic practices and better knowledge of main nutrient deficiencies in PNG would help to support feasible and viable rehabilitation techniques as judicious fertilization. Such methods might be applicable in a short term to significantly increase coconut productivity.

Between the late 50's and early 80's several fertilizer trials were conducted by the Department of Agriculture \& Livestock (DAL). Sulphur deficiency was described to be responsible for chlorosis, low yields and poor quality copra. It causes coconut palms to produce defective "rubbery" copra which has poor physical and chemical qualities (Southern, 1967). Trials conducted on New Ireland showed positive response to potassium fertilizers (Sumbak, 1971).

1 CIRAD-CP, Avenue du Val de Montferrand, BP 5035, 34032 Montpellier Cedex France.

2 PNG Cocoa \& Coconut Research Institute, PO BOX 642, Madang, Papua New Guinea. 
New coconut nutrition research approach was taken with the inception of the PNG Cocoa and Coconut Research Institute (PNG-CCRI) in 1986 and the development of a consistent coconut research activities including agronomy.

A leaf sample survey undertaken in various sites throughout the country and a mineral nutrition reference experiment under controlled conditions at Stewart Research Station (SRS) made it possible to establish an accurate picture of the nutritional status of the coconut palm and to determine the fertilizer requirements for optimum yield of coconuts.

\section{METHODOLOGY}

\section{Regional survey}

Eleven provinces of PNG were visited and one to seven sites per province were sampled. The sites are : Kisela (New Ireland Province), Kerevat, Natava, Pomio (East New Britain Province), Talasea, Nomundo (West New Britain Province), Amele, Punpun, Stewart Research Station, Omuru (Madang Province), Hawaian, Mushu (East Sepik Province), Tigare (Morobe Province), Popondetta (Oro Province), Bubuletta, (Milne Bay Province), Waima, Manabo, Maebomu (Central Province), Ihu, Iokea, Murua, Mia Kavava (Gulf Province) and Waune (Enga Province). (Figure 1).

Collection of coconut leaf samples was carried out in 1991 and 1996 on a total of 23 sites, which included smallholder blocks, plantations, DAL hybrid coconut multilocation trials and PNGCCRI research stations. Fifteen to twenty trees were randomly sampled for leaf analysis. Analysis of major elements was done by the CIRAD laboratory in Montpellier.

Soil types, where coconuts are grown, are many and derived from volcanic and sedimentary rocks. It varies from deep mature tropical latosols to immature volcanic and alluvial soils.

Study of the different elements through leaf analysis is the easiest and most accurate way of studying mineral nutrition. This method makes it possible to define the level of deficiency or surplus of the nutrient elements in the plant and it gives a good picture of the nutrition status of the coconut palm and permits to reflect the incidence of the growing environment.

\section{Stewart Research Station experiment}

A mineral nutrition trial named PNG-CCRI 801 was undertaken when the PNG-CCRI established a new station on the mainland of PNG in 1996. The land selected for the trial was previously a running down plantation and was covered with cacao under Leucaenia leucophyla as a shade in the years 1950-1960. In the last decade, due to lack of maintenance, cocoa trees died and a secondary re-growth was the initial situation of the area when the trial was initiated.

\section{Soil and climatic conditions}

Preparation of land consisted of a first manual clearing carried out in mid-1993 followed by a mechanical windrowing in 1995. The area was fully cover-cropped with Pueraria phaseloides, 5 to 6 months after planting.

The experiment located very close to the sea was established partly on the beach ridge and partly on the backplain. These coastal plain soils are described to be formed from alluvium, beach deposit alluvial deposits and volcanic ash deposit.

The shallow soils $(<50 \mathrm{~cm})$ of the beach ridge are very dark greyish fine loamy sands and 50 $100 \mathrm{~cm}$ soils are black and very dark brown fine sandy loam to dark brown and yellowish brown fine and medium loamy sands. These soils are classified as typic tropopsaments (USDA soil taxonomy). 
The backplain soils are very friable black and very dark greyish brown clay loams grading into dark brown clays $(0-50 \mathrm{~cm})$, the sub-surface horizons are dark brown and dark yellowish brown clays overlying brown and dark brown fine and medium sandy clay subsoils. These backplain soils are classified as Udolls.

Soil chemical analyses have been carried out by the DAL Soil Chemical Laboratory in 1993. Results are presented in Table 1 and 2.

The climatic conditions of SRS are very good i.e. mean annual rainfall recorded is $3,533 \mathrm{~mm}$ (42 years of record at Madang). The rainy season has a peak between November and May and a dry period centred on July to September. Water deficit is very rare. However, El Nino effect was observed at SRS from June to November 1997 and only $55 \mathrm{~mm}$ of rain were recorded from July to August 1997. Mean temperature recorded in Madang is $26.5^{\circ} \mathrm{C}$ varying from $23.1^{\circ} \mathrm{C}$ minimum mean to $30.0^{\circ} \mathrm{C}$ maximum mean.

\section{Experimental design}

The trial was planted in January 1996 with a density of 160 palms per hectare. The design is a factorial $3^{3}$ design subdivided $\times 2$, consisting of 12 experimental useful palms per treatment surrounded by 18 palms used as guard rows.

The palms used are three hybrids produced at Omuru seedgarden in Madang province. Each block of 18 plots was planted with one hybrid type as follows, using Malayan Red Dwarf as mother parent:

Block 1:MRDxKKT3- Ulatava (Karkar origin, Madang Province)

Block 2: MRD x GLT2 - Raulawat (East New Britain Province)

Block 3: MRD x OLT3 - Kikibator (Oro Province)

Trenches were excavated all around each elementary plot to avoid poaching. Standard maintenance is carried out as good drainage and regular ring weeding.

\section{Fertilizer treatments}

Nitrogen, phosphorus, potassium and chlorine elements are studied. The fertilizer rates applied per tree and per year are showed in Table 3.

Leaf samples were collected from the 12 useful coconut trees per plot. 54 plots were sampled in October 1997 on the frond of rank 9 (F9) and October 1998 on the frond of rank 14 (F14).

Vegetative growth has been recorded for the first three years. The variables observed every 6 months are the Collar Girth Circumference (CGC), the number of frond emitted in the 6 month period between 2 observations (NFE) and the length of the frond of rank 4,9 or 14 (LF):

Flowering and early stage production observations have been done every three months when flowering started. The variables observed are the percentage of sexualized palms at the observation date, the emission of unopened inflorescences, the emission of opened inflorescences, the number of bunches with nut set (fist size) per palm and number of nuts per palm accounted in the 3 month period between 2 observations.

Preparation and conditioning of samples for leaf analysis for both PNG survey and fertilizer trial have been done. Identification, collection, drying of the leaflets and packaging of the leaf samples have been prepared following the method described by Martin (1977), Ochs et al. (1977) and de Taffin et al. (1991). The samples were despatched to CIRAD France for analysis. 


\section{RESULTS}

\section{Regional survey}

Results of the leaf analysis carried out through PNG gives additional indications of the coconut growing environment in the major producing provinces such as East New Britain, Madang, New Ireland, West New Britain, Milne Bay, East Sepik, Morobe, Central, Oro and Gulf Provinces. Only North Salomon Province was not surveyed (Table 4).

\section{Study of the different elements for the regional survey}

Nitrogen: The leaf analysis shows low levels of nitrogen in most of the sites sampled in PNG. The lowest nitrogen levels were found at Punpun in the Madang province with $1.201 \%$. This particular sample was collected in a farmer block on very poorly yielding palms and performances of the palms are most probably correlated to this very severe deficiency. Low levels are also observed at Amele (Madang province), Iokea and Ihu (Gulf province) and Mushu (East Sepik province).

The highest levels (above $2.0 \%$ ) were found at Nomundo, from a well maintained plantation and Stewart Research Station (SRS) where good legume cover crop was established. This increased the organic matter which gave excellent results. Nitrogen levels in the International Germplasm collection of Talls planted in 1994 increased from $1.62 \%$ in 1996 to $2.09 \%$ in 1998. Maebomu (Central province) and Kisela (New Ireland) with $2.06 \%$ revealed relatively good nitrogen levels on the coconut hybrid palms.

Phosphorus: Most of the plots show levels above $0.120 \%$ of the dry matter with some exceptions for Waima (Central province) and Ihu with P levels of $0.112 \%$ and $0.113 \%$ respectively.

Potassium: Results show that potassium contents vary considerably with site. It ranged from $0.238 \%$ of dry matter indicating a very strong deficiency to $1.49 \%$ which is a very high $\mathrm{K}$ leaf content indicating a very good nutrition in potassium.

Very low levels of potassium were found in some sites of Central province such as the Manabo seedgarden $(0.238 \%$ on the Rennell talls). Low levels were also recorded at Bubuletta (Milne Bay province), Kisela (New Ireland Province) and Pomio (East New Britain province).

Calcium: Most of the sites sampled ranged between $0.30 \%$ and $0.40 \%$ which is considered satisfactory. High Ca levels of $0.56 \%, 0.54 \%, 0.50 \%$ are observed at Mushu, Kisela and Tigare which are characterized by coral soils. The lowest levels $(0.20-0.30 \%)$ are found in the Gulf province.

Magnesium: Leaf analysis results of the hybrids at Natava and Talasea and on the Talls at Popondetta showed low Magnesium (Mg) levels (0.15- $0.20 \%)$ when K contents are high $(>1.30 \%)$. Other sites show sufficient to high levels of $\mathrm{Mg}$ in the fronds. Central and Gulf provinces showed highest levels compared to others provinces ranging from $0.30 \%$ to $0.64 \%$.

Sodium: In the PNG leaf analysis survey, Sodium was not analyzed.

Chlorine: Chlorine levels vary considerably with site, ranging from extremely low levels $(0.009 \%$ of the dry matter) to very high values $(0.962 \%)$ with Central and Gulf provinces recording the highest. However Murua and Ihu (Gulf province) situated more inland show lower levels than other sites located on the coast. Same conclusions were achieved in the Island region. Sites at Natava, Pomio and Kisela revealed high chlorine contents in the fronds.

On the other hand, Kerevat located inland about $15 \mathrm{~km}$ from the coast show very low levels of chlorine of $0.07-0.14 \%$ range. Sites located on the west coast of New Britain also display lower levels of chlorine, such as Nomundo and Talasea. At Nomundo plantation, local tall coconuts 
sampled on the beach had $0.40 \%$ of $\mathrm{Cl}$ against $0.25 \%$ on coconut planted in the same plantation but more inland.

Nevertheless, $\mathrm{Cl}$ levels recorded from sites located along the north coast of PNG mainland, (East Sepik, Madang and Oro provinces) are very low and revealed a very severe deficiency. The lowest levels were observed at Amele situated $10 \mathrm{~km}$ inland near Madang $(0.04 \%$ for talls, $0.05 \%$ for hybrids), Popondetta-Oro (0.06 \% on talls), Tigare-Morobe $(0.07 \%)$, Hawaian-East Sepik $(0.09$ $\%$ ) and even Mushu which is a small island off shore of Wewak (East Sepik province) with $0.10 \%$ ).

The worst result was obtained at Waune and Waunekipa in the Kompiam district (Enga province) on local tall coconuts with $\mathrm{Cl}$ levels of $0.007 \%$ and $0.012 \%$ respectively.

Sulphur: The survey reveals sulphur level under the critical level only on one site of the total number of the sites observed at Waima-Central with $0.09 \%$ for the talls and $0.11 \%$ for the hybrids.

Boron: All the sites surveyed in PNG had levels ranging from 8.6 to $16.2 \mathrm{ppm}$.

\section{Stewart Research Station experiment}

The effect of treatments on the frond levels of the major elements in the in the coconut fertilizer trial are presented in Table 5.

\section{Study of the different elements for the Stewart Research Station experiment}

Nitrogen: The overall level of nitrogen in frond 14 of this trial was found to be rather low in 1998 with a mean of $1.89 \%$ of the dry matter. But a very positive effect of urea and ammonium sulfate applications were recorded for nitrogen leaf levels in 1997 and confirmed in 1998. The same proportion increase in the levels $(+5 \%)$ was observed in both years (Table 5 and 6). Nitrogen levels were also increased in the presence of sodium chloride $(\mathrm{NaCl})$ applications (Table 6). The levels found on frond of rank 9 (F9) in 1997 were quite low (mean of $1.71 \%$ ).

Phosphorus: TSP applied showed a significant increase in P levels in 1997 but this effect was not found in 1998 analysis. Same trend for $\mathrm{NaCl}$ which was found to have effect on the P levels in 1997 but not in 1998. Some depressive effect of $\mathrm{K}_{2} \mathrm{SO}_{4}$ on P levels was found in 1998 but was not as limiting factor $(0.133-0.136 \%)$.

Potassium: To date, no effect of potassium sulfate applications on $\mathrm{K}$ levels was observed. The levels of $\mathrm{K}$ are found in a range of $0.9 \%$ to $1.2 \%$ of dry matter which appears sufficient. This is in accordance with the high potassium contents found with the soil analysis results. A little depressive effect of $\mathrm{NaCl}$ on $\mathrm{K}$ levels was found in 1998 but not under $0.9 \%$ and was not a limiting factor.

Calcium: The depressive effect of Urea/Ammonium sulfate and sodium chloride which was observed on Ca levels in 1997 (lowest level 0.39\%) was not observed in 1998. A depressive effect of $\mathrm{P}$ on Ca levels with chlorine was observed in 1998.

Magnesium: The average magnesium level in the fertilizer trial at SRS was $0.26 \%$ of dry matter which is sufficient.

Sodium: Sodium chloride application significantly raised the levels of sodium in 1997 on frond of rank 9 from $0.069 \%(\mathrm{Cl})$ up to $0.088 \%(\mathrm{Cl})$ and on frond 14 in 1998 in the same proportion $(+25 \%)$ from $0.119 \%(\mathrm{Cl} 0)$ to $0.150 \%(\mathrm{Cl} 1)$.

Chlorine: Despite the location of the trial, a very strong effect of $\mathrm{NaCl}$ application was observed in the $\mathrm{Cl} 1$ levels as described in the Table 7. 
The gap between $\mathrm{Cl0}$ and $\mathrm{Cl} 1$ levels found in the leaves increased from 1997 to 1998. In 1997, the level of $\mathrm{Cl}$ in the palms which received $\mathrm{NaCl}$ was twice compared to the palms without any salt applied, in 1998; the difference is four times bigger. There is now 4 times more chlorine in the Cl1 palms than in the Cl0 palms. The 1998 leaf analysis amplified what was found in 1997 and confirmed the tremendous effect of $\mathrm{Cl}$ fertilization on leaf $\mathrm{Cl}$ contents (Table 5).

Sulphur: At SRS, a positive effect of potassium sulfate was found in 1997 and 1998 on sulphur levels in the leaves. The $\mathrm{S}$ levels increased respectively from $0.153 \%$ (K0) to $0.180 \%$ (K2) in 1997 and in a lesser proportion from $0.189 \%$ (K0) to $0.207 \%$ (K2) in 1998.

Boron: A depressive effect of $\mathrm{NaCl}$ on boron levels was found significant in 1998 leaf analysis. The average level in the trial was low with only $8.05 \mathrm{ppm}$, and visual symptoms of terminal leaflets welded together were found scattered in the trial.

\section{Results of fertilizer treatments on the growth and precocity in PNG-CCRI 801 experiment.}

The significant differences found during the juvenile stage of the growth of the palms are detailed (Table 8).

The Table 8 results show a positive response of $\mathrm{N}$ application in the early stage with effects on the number of fronds emitted: 27.8 fronds emitted for N1 and N2 against 25.1 for N0 palms $(+10 \%)$ during the $05 / 1996$ to $04 / 1998$ period. It also increased by $19 \%$ the length of frond 9 in 1997 on N1, and this, 22 months after planting.

Significant effects of chlorine are noted on most of the variables observed during the first 3 years of growth. The effect is highly significant on the collar girth for the 5 observations. For the number of frond emitted, chlorine effect was very significant during the 18 months of growth, after this no more effect was found. An inverse situation was recorded for frond length. No effect is found in the first year and significant response in October 1997 and April 1998.

The positive effect of nitrogen and chlorine found in the vegetative growth is logically found again in the flowering precocity as shown in Table 9 with high significant differences until October 1998. Three years after planting, most of the coconuts are flowered and the percentage of flowering is no more a discriminant factor.

Again, it was observed that the number of spathes emitted in the 6 month period from April to October 1998 nearly doubled when ammonium sulfate was applied. The effect of nitrogen was also highly significant on the number of nut set per palm within the July 1998 - January 1999 period $(\mathrm{N} 2:+354 \%)$. Sodium chloride also increase significantly the number of spathes emitted $(\mathrm{Cl} 1$ : $+125 \%)$ in $1998 . \mathrm{NaCl}$ is found significant on the number of nuts/palm observed in January 1999 (Cl1: $+143 \%)$ (Table 10).

\section{DISCUSSION}

At SRS, low level of nitrogen in the fronds observed in 1997 and 1998 may be related to relative poorness of the soil in organic matter at origin of the trial. It is probable that organic matter will build up with the good establishment of the Pueraria phaseloides cover and consequently the nitrogen fertilizer requirements will decrease with time.

However, from the growth characters observed in the PNG-CCRI 801 experiment, it was evident that nitrogen was one the elements which was found to be improving the growth and the precocity of coconut during its early stage of development.

In PNG, the causes of the low levels of nitrogen vary with location. It might be linked to low rainfall in the Central Province in sites such as Waima where nitrogen content is respectively $1.34 \%$ 
for the Talls and $1.38 \%$ for the hybrids. In this particular area, only 1,182 $\mathrm{mm}$ of rain are recorded per year with a severe dry season from May to November.

Other causes are linked to soil conditions unfavorable to the mineralization of the organic matter (coral lands, white sands leached by a very high water table or swampy areas) and faulty maintenance encouraging the spread of grasses especially Imperata cylindrica, all high consumers of nitrogen. It can also result from exhaustion of the soil by many years of cropping. Quite a high diversity (between $0.17 \%$ to $0.95 \%$ ) and a $\mathrm{C} / \mathrm{N}$ ratio (8-14 range) were recorded in top soil samples of cocoa and coconut growing environments throughout PNG (Hanson et al., 1998).

In the PNG-CCRI 801 trial it was clear that phosphorus applications did not induce direct effect on growth. The native content of total phosphorus in the soil is the major determinant factor and above $120 \mathrm{ppm}$, requirements are satisfied (R. Manciot et al, 1980). P leaf analysis contents over $0.120 \%$ are found acceptable, and that is mostly the case for all the sites surveyed. The two exceptions with low levels at Waima and Ihu can be explained because of the close relation N-P liaison where nitrogen-deficient nutrition can lead to a fall in the phosphorus levels.

The PNG-CCRI 801 experiment showed that potash applications do not induce direct effect on growth and precocity of the palm. Number of palms flowered after 34 months in treatment K0Cl1 (57\%) were found to be better than $\mathrm{K} 2 \mathrm{Cl} 10$ (49\%). This observation proved that sodium chloride was a more effective fertilizer than potassium sulfate. It was also observed that, in the presence of chlorine, the application of potassium sulfate had a depressive effect on the precocity and the early stage of production. Number of palm flowering after 34 months in treatment K2Cl1 (48\%) was found lower than K0Cl1 which was confirmed with the number of nut set per palm in the July 1998January 1999 period (9.1 nut/palm for K0Cl1 against 6.9 nut/palm for K2Cl1). The K1Cl1 (with 13,6 nut per palm) seems to be a better treatment with a better balance between $\mathrm{K}$ and $\mathrm{Na}$.

$\mathrm{K}-\mathrm{Cl}$ interaction was found significant in the result and most probably related to the K-Na antagonism. This was also observed at Gunung Batin in Indonesia (Bonneau, 1997). Chlorine is the dominant element and potassium only reveals its effect if the chlorine effect is removed: 4.9 nuts/palm for K0Cl0 against 9.4 nuts/palm for K2Cl0 for the July 1998-January 1999 period.

The situation found at SRS cannot be generalized, as potassium distribution in the soil is related to rock type. Potassium availability depends on its relation with other cations. High calcium or magnesium soil content can depress potassium availability. The levels of exchangeable potassium in top soils sampled in the major coconut producing areas fluctuate from 0.05 meq in Milne Bay province to $9.73 \mathrm{meq}$ in Morobe province. Potassium deficiencies have been reported by Baseden and Southern (1959) in coconut palms growing on coral-derived soils along the east coast of New Ireland. This is confirmed by leaf analysis carried out at Kisela in New Ireland where one of the lowest level leaf content $0.360 \%$ of $\mathrm{K}$ was. The authors conclude that soils containing less than $0.6 \mathrm{meq} \%$ potassium are unlikely to produce optimum coconut yields, and have inadequate reserves for continued healthy growth without fertilizer applications. Coastal sands, coral soils or lateritic soils often shows K levels below $0.15 \mathrm{meq} / 100 \mathrm{~g}$ compared to other soils with high native potassium content . This is the case of most soils sampled in New Ireland and Milne Bay. Only on ash soils of volcanic origin with high exchangeable $\mathrm{K}$ such as most of East New Britain (with the exception of Pomio) and West New Britain, got leaf contents often close to the critical level with little or no need for correction. Morobe province show also good exchangeable potassium content in soil. (L.W. Hanson et al,1998). The K level in the frond observed at Tigare was found sufficient.

In the Central Province near Cape Rodney, high exchangeable magnesium content in soil, coupled with very low exchangeable potassium content may give rise to serious deficiency symptoms in coconut palms (Sumbak and Best 1976). This is also confirmed with the analysis made at Manabo seedgarden located near Cape Rodney where the lowest levels were observed $(0.238 \%$ on tall and 
$0.306 \%$ on dwarf coconuts). Visual symptoms and very low yielding trees were clearly observed during leaf sample collection.

Fertilizer trials carried out in this region have shown good responses with large initial applications necessary (Sumbak and Best .1976). Best (1977) concluded that there may be other areas in the south-eastern part of PNG with similar problems. The leaf diagnosis results from Milne Bay, Central and even Gulf provinces confirm best's assumptions. It is also observed that low $\mathrm{K}$ levels in the fronds are often coupled with high levels of $\mathrm{Mg}$ (above $0.3 \%$ ).

The production is known to be closely linked to potassium contents (R. Manciot et al, 1980). This observation is all the more important that hybrid material is likely to produce high yields. Furthermore, if the husk, responsible for a large proportion of total exports is not returned to the soil (i.e. husk use as fuel to dry copra), requirements are even higher. Also, initial richness of potassium in the soil can be heavily compromised by exhausting food crops.

The highly significant positive correlation between leaf contents and copra per tree was observed in Hawaiian and Mushu demonstration plots located close to each other in East Sepik province. These plots have very high difference in K leaf contents; Mushu situated on a coral derived soil show very low $\mathrm{K}$ levels of $0.647 \%$ against $1.49 \%$ for Hawaiian on the mainland. Coconut production recorded by Ovasuru (1998) show 41.6 nuts/palm/year and $7.7 \mathrm{~kg}$ of copra/palm/year at Mushu against 74.1 nuts/palm/year and $12.8 \mathrm{~kg}$ of copra/palm/year at Hawaiian for the MRD x RIT hybrid.

Magnesium deficiency is said to appear on soils poor in this element or be provoked by large potassium applications which could depress the Mg levels. The richness of magnesium in the PNG soils would more often induce an unbalanced $\mathrm{Mg}-\mathrm{K}$ ratio detrimental to potassium nutrition. The soil analysis carried out in the main coconut producing provinces revealed high $\mathrm{Mg}$ levels (range of 1.41$14.82 \mathrm{me}$ in the top soil and 0.16-25.6 me in the subsoil) and it is unlikely that magnesium be a nutritional problem for coconut in PNG. In the leaf analysis results it was clear that potassium deficiencies were more often found than magnesium deficiencies.

However, the K-Mg antagonism is well known. It was detected in the leaf analysis results of the hybrids at Natava, Talasea and the Talls at Popondetta where magnesium levels are quite low $(0.15-0.20 \%)$ and where $\mathrm{K}$ contents are high (>1.30). Apart from these 3 locations, the other sites show sufficient to high levels of magnesium in the fronds.

Wide spread occurrence of sulfur deficiency cause chlorosis, low yield and poor quality copra (Southern. 1967). The critical sulphur level for a leaf of rank 14 should be of $0.15-0.20 \%$ of the dry matter depending of the edapho-climatic conditions and the nitrogen nutrition. The rate N/S has to be between 10/1 and 13/1. Of the total sites observed, only Waima reveals a sulphur level under the critical level with $0.09 \%$ for the talls and $0.11 \%$ for the hybrids. This result is related to the low level of nitrogen observed on this particular site. According to the present survey, sulphur doesn't seem to be a major problem for the coconut nutrition. Sulphur symptoms are often observed where palms are grown in waterlogged and poorly drained areas.

Little is known about the trace element contents of PNG soils, but some studies were carried out by Southern and Kay Dick (1969) to diagnose characteristic symptoms of B deficiency through leaf analysis and critical level varies between 5 and 10ppm, depending on the site.

Typical boron deficiency symptom is often seen on palms at SRS; sometimes on palms that are already old. In most cases, they are only slight deficiency symptoms: welded leaflets, hooked leaflet tips, puckered leaflet tissue. However, in a few rarer cases, serious deficiency symptoms have been observed where emission of fronds with completely fused leaflets, then emission of stumps and palm death. 
The latest leaf analysis in trial PNG-CCRI 801, revealed a mean B content of 8 ppm with a minimum of $6.7 \mathrm{ppm}$. In most cases, these contents are enough. However, boron deficiencies are more frequent especially when young coconut growth is very rapid (boron-cation imbalance) which is the case at Stewart Research Station.

\section{Chlorine an important nutritional factor in PNG}

The chlorine effect found in the trial PNG-CCRI 801 at SRS was surprising. All the results showed that salt applications had positive effect on the growth, the precocity and preliminary results show effect on the early production. This chlorine effect was not really expected due to the location of the trial (100 meters from the sea). These results reveal a very severe natural chlorine deficiency, indicating that chlorine from the atmosphere is negligible.

Although the chlorine deficiency doesn't have any extreme effect on the coconut palms at SRS, due to the absence of any water stress, chlorine fertilizers are nevertheless effective. Ample and regular applications of $\mathrm{KCl}$ and $\mathrm{NaCl}$ are therefore recommended in order to reach a level of $0.5 \%$ in leaf 14.

For the current, given that sodium chloride $(\mathrm{NaCl})$ is no cheaper locally than potassium chloride $(\mathrm{KCl})$, calculation of the most effective $\mathrm{KCl} / \mathrm{NaCl}$ combination is not an urgent requirement. However, consideration could be given (e.g. if PNG one day produces a cheap sea salt) to setting up a new mineral nutrition trial at the station, studying both the optimum chlorine fertilizer rate and the optimum proportions of $\mathrm{KCl}$ and $\mathrm{NaCl}$.

It is known that chlorine is an essential element for the yield of coconuts and for drought resistance as described in Indonesia (Bonneau et al, 1997). Chlorine levels in the fronds are closely correlated to production per tree and chlorated manuring affects both the number of nuts produced and the copra per nut in number of coconut producing countries such as Philippines (Magat, 1998). Most soils contain very little chlorine and the natural supply is provided by atmospheric deposit. The deposit by precipitation is closely linked from a quantitative point of view to local meteorological conditions. It was observed in Ivory Coast that chlorine deposit decrease exponentially and rapidly with respect to the distance to the coast (Delmas et al, 1983).

While the local climate is strongly related to topography, the major climatic controls are influenced by seasonal latitudinal movements of two air masses (Mc Alpine et al., 1982). The North West winds prevail from late December to mid April and they are associated with heaviest and most frequent rainfalls. South east winds also known as trade winds, which blow with great regularity over the Coral Sea (southern sea of mainland PNG) between May and October, do not produce frequent heavy rainfall.

The mean monthly vector winds recorded in 5 major meteorological stations give a fair idea of the conditions required for possible transfer of chlorine to the palms (Table 11). Wind direction and speed at surface levels display very different conditions between the south and the north of the mainland and the islands.

Measurements to evaluate the chlorine deposit have never been carried out in PNG. But, according to the wind flow recorded in the Torres Strait and in Port Moresby, it is likely that dry chlorine deposit would be abundant on the southern coast during the trade wind period. Aerodynamic conditions close to the ground would suggest that concentration of chlorine in the aerosols would be high.

The chlorine content found in the leaf analysis carried out in the Gulf, Central and even Milne Bay province are confirming such hypothesis. It was found in Ivory Coast that total chlorine deposit (dry and moist) decreases considerably from 107,2 kg/ha between 0-10 km from the coast to $17.8 \mathrm{~kg} / \mathrm{ha}$ between $180-200 \mathrm{~km}$. 
Another scenario is found on the north coast of the mainland. In Madang and Lae, winds are predominantly west - north west and stronger during the monsoon period compared to the trade wind period. This is probably due to the topography; the south east winds are blocked by the central ranges region.

The ground speed of wind in Madang is low all the year around. This might be an important factor in that it may reduce the bubbling phenomenon involved in the formation of marine aerosols which are directly linked to the strength of the wind on the surface of the sea.

It is obvious that coconut planted in Enga province where lowest chlorine levels are reported, will never produce large quantities of nuts if any appropriate correction is carried out. The area where the sample was collected is situated at about $220 \mathrm{~km}$ from the Southern coast and $120 \mathrm{~km}$ from the northern coast of the mainland. This extreme position can explain such figures.

\section{CONCLUSION}

The nutritional status of coconut taken from various soil and climatic contexts and obtained through leaf diagnosis can partly explain the relatively low level of coconut productivity in PNG. Mineral nutrition experiment such as the PNG-CCRI 801 trial is a very valuable source of information to assess the nutrient requirement of the promising hybrids to express their optimum potential.

The preliminary results of the trial revealed a very good precocity of the hybrids mainly due to excellent soil and climatic conditions of the site. Soil rich in exchangeable cations, good drainage and good rainfall. However, applications of ammonium sulfate and sodium chloride caused significant positive effects in the growth and the hanging production of the palms.

It is obvious that nitrogen and chlorine are the main limiting nutritional factors in the Stewart research Station at Madang and experiment proves that it affect all growth, flowering and early stage production variables.

The observations and the results would be helpful to draw up recommendations of fertilizer, may support prioritization of extension activities and possible design of participating coconut nutrition research trials in the field for the benefit of the farmers.

\section{ACKNOWLEDGEMENTS}

The authors would like to thank Mr. T. Ovasuru, Coconut Breeder of the PNG-CCRI who organised the collection of the leaf samples throughout Papua New Guinea. Thank also to Mr Pius Pulo and Kuregen Sik, Assistant Research Officers of the PNG-CCRI who supervised the work and collected the data in the mineral nutrition experiment. 


\section{REFERENCES}

ACIAR, 1987. Papua New Guinea Export Tree Crop Study - 2 - Largeholder Cocoa/Coconuts.

APCC, 1997. Asian Pacific Coconut Community, 1997 Coconut Statistical Yearbook.

BANGA, M., 1983. Soil survey of Murnas and Kailie Yield/ palm Plantations. Madang Province. Departement of Agriculture and Livestock - Land Utilisation Section. Report $\mathrm{N}^{\circ} 680$.

BASEDEN, S.C., SOUTHERN, P.J. 1959. Evidence of potassium deficiency in coconut palm in New Ireland. Papua and New Guinea agric. J. 11 : 101-116.

BEST, E.K., 1977. A study of potassium in a Papuan alluvial soil. MSc. Thesis, University of Papua New Guinea.

BLEEKER, P., 1983. Soils of Papua New Guinea. Commonwealth Scientific and Industrial Research Organisation. Australian National University Press. Canberra.

BONNEAU X., BOUTIN D., BOURGOING, R., SUGARIANTO, J., 1997. Le chlorure de sodium, fertilisant idéal du cocotier en Indonésie. Plantations, recherche, developpement, 4 (5):336346.

BONNEAU X. 1999. Report on the visit to the Stewart Research Station, CCRI Madang, Papua New Guinea. Doc. Cp 1104.

DELMAS R., DJOUKA, A., 1983. Etude des apports atmosphériques de chlore aux sols en Basse Cote d'Ivoire. Oleagineux, 38 (7).

De TAFFIN G., ROGNON, F., 1991. Le diagnostic foliaire du cocotier. Conseils de l'IRHO 318. Oleagineux 46 (4): 170-171.

HANSON, L.W., BOURKE, R.M. and YINIL, D.S., 1998. Cocoa and Coconut Growing Environments in Papua New Guinea. A Guide for Research and Extensions Activities. Australian Agency for International development.

MAC ALPINE, J.R., KEIG, G., SHORT, K., 1975. Climatic tables for Papua New Guinea. Division of land use research technical paper $\mathrm{N}^{\circ} 37$. CSIRO. $177 \mathrm{p}$.

MARTIN, G., 1977. Preparation and conditioning of samples for leaf analysis of oil palm and coconut. Conseils de l'IRHO 170. Oleagineux 32 (3): 95-98.

MAGAT, S., 1998. Coconut rehabilitation techniques \& post-rehabilitation technologies to sustain coconut production. Cocotech- APCC Bali : 1-34.

MANCIOT, R., OLLAGNIER, M., OCHS, R., 1980. Nutrition minérale et fertilisation du cocotier dans le monde. Oleagineux $35 \mathrm{~N}^{\mathrm{O}}$ hors serie.

OCHS, R., OLIVIN, J., 1977. Leaf analysis for the control of nutrition in oil palm plantations. Taking of leaf samples. Conseils de l'IRHO 172. Oleagineux 32 (5): 211-216.

OVASURU, T. 1999. Mid-Term Research Review. PNG Cocoa \& Coconut Research Institute. Internal document. 
SOUTHERN, P.J., 1967. Sulfur deficiency in Coconuts, a widespread Field Condition in Papua and New Guinea. Part I. The field and Chemical Diagnosis of Sulfur Deficiency. Papua and New Guinea agric. $J$.

SUMBAK, J.H., 1976. Progress of two Coconut Fertilizer trials in Papua New Guinea. Oleagineux, $31(10)$ :

Figure 1: Soil analysis - Beach ridge-Stewart Research Station

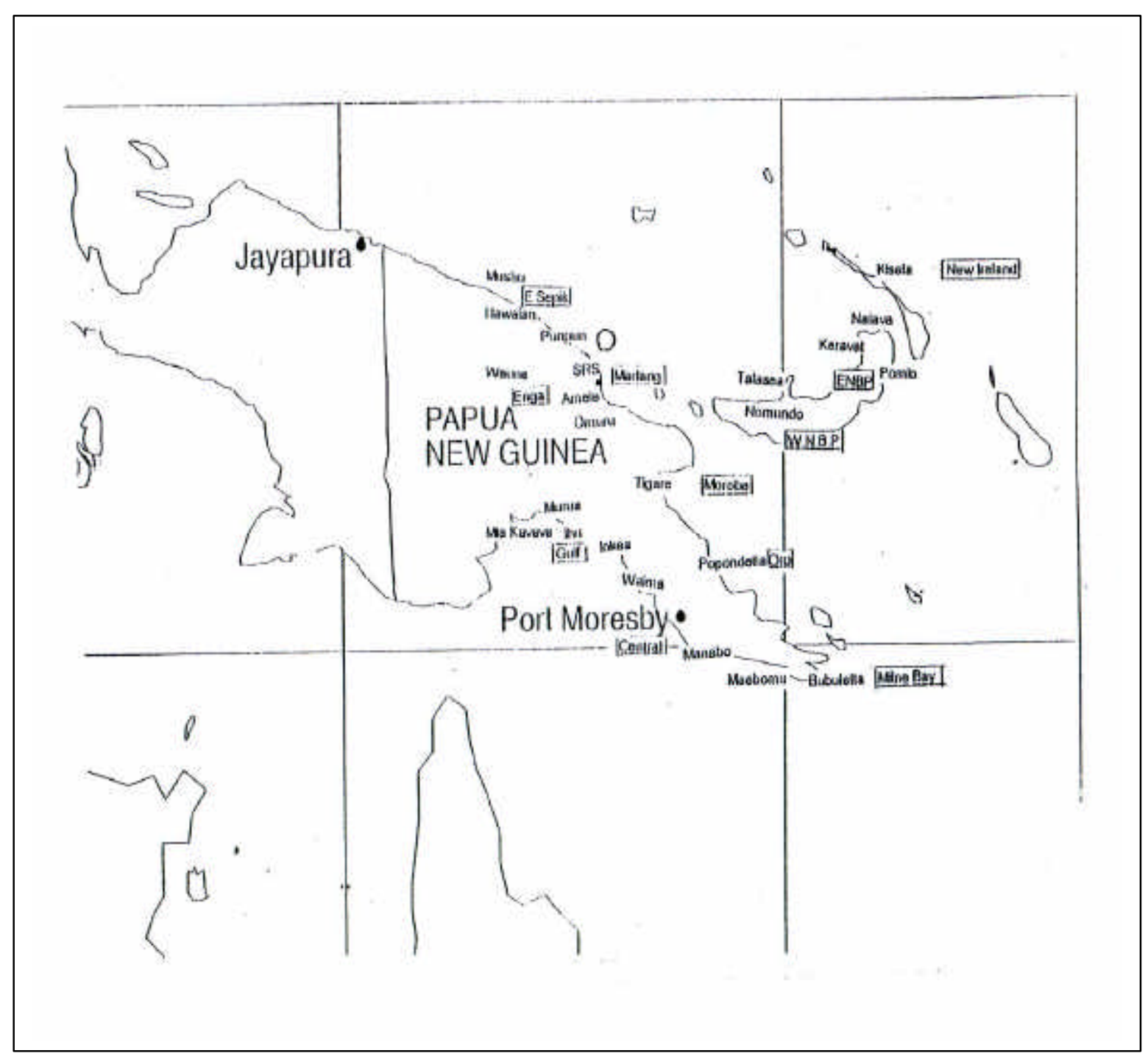




\begin{tabular}{|c|c|c|c|c|c|c|c|c|c|c|c|c|c|}
\hline \multirow{2}{*}{$\begin{array}{l}\text { Depth } \\
\mathrm{cm}\end{array}$} & \multirow{2}{*}{$\mathrm{pH}$} & \multicolumn{3}{|c|}{ Exch. Bases (meq\%) } & \multirow{2}{*}{ CEC } & \multirow{2}{*}{$\begin{array}{l}\text { B.S. } \\
\%\end{array}$} & \multirow{2}{*}{$\begin{array}{l}\text { P Total } \\
\text { Olsen ppm }\end{array}$} & \multirow{2}{*}{$\begin{array}{l}C \\
\text { org }\end{array}$} & \multirow{2}{*}{$\begin{array}{l}\mathrm{N} \\
\text { Tot }\end{array}$} & \multirow{2}{*}{$\mathrm{C} / \mathrm{N}$} & \multicolumn{3}{|c|}{ Particle size \% } \\
\hline & & $\mathrm{Ca}$ & $\mathrm{Mg}$ & K & & & & & & & sa & si & $\mathrm{cl}$ \\
\hline $0-12$ & 6.6 & 28.7 & 3.87 & 2.10 & 44.9 & 77 & 15.8 & 7.57 & 0.59 & 13 & 54 & 22 & 24 \\
\hline $12-33$ & 6.9 & 19.9 & 1.61 & 0.91 & 33.2 & 68 & 6.1 & 3.21 & 0.25 & 13 & 51 & 19 & 30 \\
\hline $33-62$ & 6.8 & 14.5 & 2.23 & 0.69 & 26.8 & 66 & 4.6 & 1.42 & 0.08 & 18 & 62 & 15 & 23 \\
\hline $62-90$ & 6.8 & 17.2 & 7.80 & 0.95 & 34.1 & 76 & 8.9 & 0.35 & 0.03 & 12 & 68 & 8 & 23 \\
\hline $90-112$ & 7.0 & 14.5 & 5.40 & 0.86 & 26.3 & 79 & 14.6 & 0.37 & 0.03 & 12 & 79 & 2 & 19 \\
\hline $112-130$ & 7.0 & 18.6 & 8.35 & 0.23 & 34.1 & 80 & 7.1 & 0.15 & 0.02 & 8 & 73 & 8 & 19 \\
\hline
\end{tabular}

Table 2: Soil analysis - Back Pain - Stewart Research Station

\begin{tabular}{|c|c|c|c|c|c|c|c|c|c|c|c|c|c|}
\hline \multirow{2}{*}{$\begin{array}{l}\text { Depth } \\
\text { cm }\end{array}$} & \multirow{2}{*}{$\mathrm{pH}$} & \multicolumn{3}{|c|}{ Exch. Bases (meq\%) } & \multirow{2}{*}{ CEC } & \multirow{2}{*}{$\begin{array}{l}\text { B.S. } \\
\%\end{array}$} & \multirow{2}{*}{$\begin{array}{l}\text { P Total } \\
\text { Olsen ppm }\end{array}$} & \multirow{2}{*}{$\begin{array}{l}C \\
\text { org }\end{array}$} & \multirow{2}{*}{$\begin{array}{l}\mathbf{N} \\
\text { Tot }\end{array}$} & \multirow{2}{*}{ C/N } & \multicolumn{3}{|c|}{ Particle size \% } \\
\hline & & $\mathrm{Ca}$ & $\mathrm{Mg}$ & $\mathrm{K}$ & & & & & & & sa & si & $\mathrm{cl}$ \\
\hline $0-15$ & 6.2 & 24.8 & 6.42 & 1.72 & 38.1 & 86 & 4.7 & .88 & 0.52 & 15 & 37 & 33 & 29 \\
\hline $15-30$ & 6.2 & 17.6 & 6.97 & 0.21 & 30.2 & 83 & 4.2 & 3.86 & 0.26 & 15 & 35 & 31 & 34 \\
\hline $30-58$ & 5.8 & 17.2 & 8.65 & 0.15 & 32.0 & 82 & 1.1 & 0.96 & 0.11 & 9 & 30 & 21 & 48 \\
\hline $58-92$ & 6.2 & 20.6 & 9.25 & 0.12 & 29.4 & 100 & 2.0 & 0.24 & 0.03 & 8 & 50 & 13 & 37 \\
\hline $92-130$ & 6.2 & 19.2 & 8.02 & 0.15 & 31.6 & 88 & 8.4 & 0.17 & 0.03 & 6 & 61 & 11 & 28 \\
\hline
\end{tabular}

\begin{tabular}{|c|c|c|c|c|c|c|c|c|c|c|c|}
\hline \multirow{2}{*}{$\begin{array}{l}\text { Type } \\
\text { Date }\end{array}$} & \multicolumn{3}{|c|}{$\begin{array}{c}\text { Urea (1996) } \\
\mathrm{NH}_{4} \mathrm{SO}_{4}(1997-1998)\end{array}$} & \multicolumn{3}{|c|}{ TSP } & \multicolumn{3}{|c|}{$\begin{array}{c}\text { Sulfate of Postash } \\
\text { KS2SO4 }\end{array}$} & \multicolumn{2}{|c|}{$\begin{array}{c}\text { Sodium } \\
\text { Chloride } \mathrm{NaCl} \\
\end{array}$} \\
\hline & NO & N1 & N2 & PO & P1 & P2 & KO & K1 & K2 & $\mathrm{ClO}$ & $\mathrm{Cl} 1$ \\
\hline 07.96 & 0 & 150 & 300 & 0 & 150 & 300 & 0 & 300 & 600 & 0 & 500 \\
\hline 07.97 & 0 & 500 & 1,000 & 0 & 250 & 500 & 0 & 500 & 1,000 & 0 & 750 \\
\hline 06.98 & 0 & 750 & 1,500 & 0 & 500 & 1,000 & 0 & 500 & 1,000 & 0 & 1,500 \\
\hline 10.98 & 0 & 750 & 1,500 & & & & & & & & \\
\hline
\end{tabular}




\begin{tabular}{|c|c|c|c|c|c|c|c|c|c|c|c|}
\hline \multicolumn{12}{|c|}{$\begin{array}{r}\text { Table } 4 \text { : Leaf analysis results in various locations Throughout Papua New Guinea } \\
\text { E.N.B.P : East New Britain Province; W.N.B.P : West New Britain Province } \\
\text { MRD x RIT : Malayan Red dwarf x Rennell Tall ; MD x RIT : Malayan Red dwarf x Rennell Tall; } \\
\text { LT: Local Tall }\end{array}$} \\
\hline Location & Province & Variety & N\% & P\% & $\mathrm{K} \%$ & $\mathrm{Ca} \%$ & Mg\% & $\mathrm{Cl} \%$ & S\% & B ppr & Age \\
\hline Kisela & New Ireland & MRDXRIT & 2.063 & 0.156 & 0.360 & 0.545 & 0.387 & 0.445 & 0.156 & 10.8 & 1980 \\
\hline Keravat & ENBP & MDxRIT & 1.939 & 0.156 & 1.006 & 0.484 & 0.265 & 0.073 & 0.171 & & $\mathrm{Na}$ \\
\hline Keravat & ENBP & LT & 1.946 & 0.147 & 1.158 & 0.532 & 0.285 & 0.141 & 0.182 & & $\mathrm{Na}$ \\
\hline Natava & ENBP & MRDxRIT & 1.800 & 0.148 & 1.352 & 0.353 & 0.162 & 0.745 & 0.169 & 8.6 & 1980 \\
\hline Pomio & ENBP & MRDxRIT & 1.921 & 0.144 & 0.285 & 0.300 & 0.332 & 0.529 & 0.165 & 10.9 & 1980 \\
\hline Talasea & WNBP & MRDxRIT & 1.923 & 0.151 & 1.305 & 0.378 & 0.154 & 0.188 & 0.180 & 10.8 & 1980 \\
\hline Nomundo & WNBP & MD & 2.224 & 0.148 & 1.431 & 0.471 & 0.216 & 0.568 & 0.177 & & $\mathrm{Na}$ \\
\hline Nomundo & WNBP & LT & 2.126 & 0.148 & 1.584 & 0.529 & 0.265 & 0.307 & 0.177 & & $\mathrm{Na}$ \\
\hline Nomundo & WNBP & MRDxRIT & 2.016 & 0.138 & 1.525 & 0.469 & 0.214 & 0.188 & 0.181 & & $\mathrm{Na}$ \\
\hline Amele & Madang & MRDXRIT & 1.732 & 0.122 & 0.866 & 0.361 & 0.246 & 0.051 & 0.145 & 7.9 & 1981 \\
\hline Amele & Madang & LT & 1.778 & 0.122 & 0.783 & 0.401 & 0.239 & 0.046 & 0.139 & 8.8 & 1981 \\
\hline Punpun & Madang & LT & 1.201 & 0.129 & 1.335 & 0.314 & 0.273 & 0.439 & 0.135 & 11.1 & 1966 \\
\hline SRS & Madang & LT & 1.727 & 0.141 & 1.064 & 0.338 & 0.207 & 0.475 & 0.138 & 9.5 & 1935 \\
\hline SRS & Madang & LT GC & 2.095 & 0.133 & 1.040 & 0.333 & 0.250 & 0.180 & 0.207 & & 1994 \\
\hline SRS & Madang & MRDxRIT & 2.115 & 0.142 & 0.992 & 0.366 & 0.251 & 0.165 & 0.217 & & 1995 \\
\hline Omuru & Madang & MD & 1.813 & 0.141 & 1.084 & 0.396 & 0.199 & 0.225 & 0.171 & & 1993 \\
\hline Hawaian & E. Sepik & MRDxRIT & 1.883 & 0.154 & 1.490 & 0.315 & 0.242 & 0.094 & 0.151 & 16.2 & 1980 \\
\hline Mushu & E. Sepik & MRDxRIT & 1.769 & 0.128 & 0.647 & 0.564 & 0.303 & 0.102 & 0.148 & 12.6 & 1980 \\
\hline Tigare & Morobe & MRDxRIT & 1.710 & 0.142 & 1.026 & 0.501 & 0.284 & 0.076 & 0.164 & 11.2 & \\
\hline Popondetta & Oro & MRDxRIT & 1.789 & 0.151 & 1.304 & 0.312 & 0.213 & 0.046 & 0.141 & & 1980 \\
\hline Popondetta & Oro & LT & 1.772 & 0.142 & 1.340 & 0.324 & 0.208 & 0.068 & 0.140 & 11.9 & 1980 \\
\hline Bubuletta & Milne Bay & MRDxRIT & 1.926 & 0.114 & 0.437 & 0.256 & 0.330 & 0.357 & 0.149 & & 1980 \\
\hline Bubuletta & Milne Bay & LT & 1.896 & 0.116 & 0.548 & 0.288 & 0.355 & 0.750 & 0.149 & 10.4 & 1980 \\
\hline Waima & Central & MRDxRIT & 1.384 & 0.112 & 1.125 & 0.308 & 0.473 & 0.948 & 0.111 & 12.9 & 1980 \\
\hline Waima & Central & LT & 1.340 & 0.117 & 0.811 & 0.372 & 0.643 & 0.962 & 0.095 & 13.3 & 1980 \\
\hline Manabo & Central & MRD & 1.979 & 0.138 & 0.306 & 0.355 & 0.470 & 0.472 & 0.191 & & 1983 \\
\hline Manabo & Central & RIT & 1.865 & 0.142 & 0.238 & 0.461 & 0.461 & 0.219 & 0.177 & & 1983 \\
\hline Maebomu & Central & LT & 2.060 & 0.118 & 0.640 & 0.332 & 0.342 & 0.554 & 0.145 & & $\mathrm{Na}$ \\
\hline Ihu & Gulf & MRDXRIT & 1.747 & 0.113 & 0.863 & 0.220 & 0.302 & 0.239 & 0.139 & & 1980 \\
\hline Lokea & Gulf & MRDxRIT & 1.614 & 0.116 & 0.828 & 0.303 & 0.467 & 0.882 & 0.141 & 11.7 & 1980 \\
\hline Lokea & Gulf & LT & 1.753 & 0.127 & 1.020 & 0.272 & 0.421 & 0.770 & 0.148 & 13.9 & 1980 \\
\hline Murua & Gulf & LT & 1.951 & 0.135 & 1.104 & 0.273 & 0.296 & 0.281 & 0.155 & & $\mathrm{Na}$ \\
\hline Mia Kavava & Gulf & LT & 1.846 & 0.134 & 0.866 & 0.209 & 0.565 & 0.784 & 0.164 & & $\mathrm{Na}$ \\
\hline Waune & Enga & LT & 1.775 & 0.135 & 1.454 & 0.264 & 0.235 & 0.009 & 0.146 & & 1988 \\
\hline
\end{tabular}




\begin{tabular}{|c|c|c|c|c|c|c|c|cc|}
\hline \multicolumn{8}{|c|}{ Table 5: Action of fertilizers on the nutrient levels in the frond of rank 14 } \\
\multicolumn{10}{|c|}{ Leaf Analysis results year 1998 } \\
\hline & N & P & K & Ca & Mg & Na & Cl & S & B \\
\hline N0 & 1.823 & 0.139 & 1.047 & 0.334 & 0.259 & 0.093 & 0.201 & 0.193 & 8.2 \\
\hline N1 & $1.919 * *$ & 0.139 & 1.070 & 0.339 & 0.251 & 0.066 & 0.191 & $0.202^{*}$ & 8.1 \\
\hline N2 & $1.937 * *$ & 0.137 & 1.055 & 0.356 & 0.265 & 0.076 & 0.183 & $0.206^{*}$ & 7.8 \\
\hline P0 & 1.864 & 0.134 & 1.005 & 0.345 & 0.261 & 0.088 & 0.191 & 0.199 & 8.1 \\
\hline P1 & 1.914 & 0.141 & 1.130 & 0.344 & 0.249 & 0.070 & 0.196 & 0.200 & 8.1 \\
\hline P2 & 1.901 & 0.140 & 1.036 & 0.340 & 0.265 & 0.078 & 0.189 & 0.203 & 8.0 \\
\hline K0 & 1.893 & 0.142 & 1.080 & 0.354 & 0.253 & 0.078 & 0.187 & 0.189 & 8.3 \\
\hline K1 & 1.875 & 0.138 & 0.974 & 0.338 & 0.271 & 0.082 & 0.187 & $0.206 * *$ & 8.0 \\
\hline K2 & 1.911 & 0.135 & 1.118 & 0.337 & 0.252 & 0.075 & 0.201 & $0.207 * *$ & 7.9 \\
\hline C10 & 1.884 & 0.137 & 1.098 & 0.341 & 0.254 & 0.069 & 0.074 & 0.203 & $8.5 * *$ \\
\hline C11 & $1.903 *$ & 0.140 & $1.017 *$ & 0.345 & 0.263 & $0.088^{* *}$ & $0.310^{* *}$ & 0.198 & $7.6 * *$ \\
\hline
\end{tabular}

\begin{tabular}{|c|c|c|c|}
\hline & $\begin{array}{c}\text { N Level 10/1997 } \\
\text { Frond rank } 9 \\
\end{array}$ & N Level 1997 Cl 0 & N Level 1997 Cl1 \\
\hline No & 1.66 & 1.60 & 1.71 \\
\hline N1 & $1.75 * *$ & 1.71 & $1.79 * *$ \\
\hline $\mathrm{N} 2$ & $1.74 \quad * *$ & 1.73 & $1.76 * *$ \\
\hline
\end{tabular}

\begin{tabular}{|c|c|c|c|c|}
\hline \multicolumn{5}{|c|}{ Table 7 : Chlorine livels in the subdivision } \\
\hline & Chlorine livel & nd rank 9 & Chlorine levels 1 & rank 14 \\
\hline $\mathrm{ClO}$ & 0.163 & 100 & 0.074 & 100 \\
\hline $\mathrm{Cl} 1$ & $0.313 * *$ & 192 & $0.310 * *$ & 420 \\
\hline
\end{tabular}




\section{Table 8 : Significant differences on growth characters}

CGC : Collar Girth $(\mathrm{cm})$ - NFE : Number of Fronds Emitted 6 month period LF : Length of Frond rank 4/9/14 Sig. N = Statistical significance of nitrogen effect - Sin. $\mathrm{Cl}=$ Statistical significance of chlorine effect $* *=$ statistical significance at the $1 \%$ level $*=$ statistical significance at the $5 \%$ level - N.S. $=$

Not statistically significant

\begin{tabular}{|l|r|r|r|r|r|r|r|}
\hline & N0 & N1 & N2 & Sig.N & Cl0 & Cl1 & Sig.Cl \\
\hline Ten months 10/1996 & 40 & 48 & 17 & $*$ & 43 & 47 & $* *$ \\
\hline CGC & 4.5 & 5.3 & 5.3 & $* *$ & 4.9 & 5.2 & $* *$ \\
\hline NFE & 221 & 225 & 215 & N.S. & 219 & 223 & N.S. \\
\hline LF4 & 40 &
\end{tabular}

Sixteen months 04/1997

\begin{tabular}{|l|r|r|r|r|r|r|c|}
\hline CGC & 82 & 99 & 97 & N.S. & 89 & 96 & $* *$ \\
\hline NFE & 5.4 & 6.0 & 6.2 & $*$ & 5.7 & 6.1 & $* *$ \\
\hline LF9 & 260 & 286 & 289 & $*$ & 273 & 284 & N.S. \\
\hline
\end{tabular}

\section{Twenty two months 10/1997}

\begin{tabular}{|l|r|r|r|r|r|r|c|}
\hline CGC & 96 & 112 & 109 & N.S. & 102 & 109 & $* *$ \\
\hline NFE & 5.4 & 6.1 & 6.0 & N.S. & 5.7 & 5.9 & $*$ \\
\hline LF9 & 332 & 395 & 383 & $*$ & 365 & 375 & $*$ \\
\hline
\end{tabular}

Twenty eight months 04/1998

\begin{tabular}{|l|r|r|r|r|r|r|c|}
\hline CGC & 144 & 148 & 143 & N.S. & 143 & 147 & $* *$ \\
\hline NFE & 9.9 & 10.4 & 10.3 & $* *$ & 10.1 & 10.2 & N.S. \\
\hline LF14 & 422 & 480 & 459 & N.S. & 449 & 459 & $*$ \\
\hline
\end{tabular}

\section{Thirty four months $\mathbf{1 0 / 1 9 9 8}$}

\begin{tabular}{|l|r|r|r|r|r|r|l|}
\hline CGC & 166 & 171 & 167 & N.S. & 166 & 171 & $* *$ \\
\hline NFE & 9.4 & 9.6 & 9.6 & N.S. & 9.5 & 9.6 & N.S. \\
\hline LF14 & 486 & 521 & 509 & N.S. & 502 & 509 & N.S. \\
\hline
\end{tabular}




\begin{tabular}{|c|c|c|c|c|}
\hline \multicolumn{5}{|c|}{ Table 9 : Effect of Nitrogen and Chlorine on precocity } \\
\hline $\begin{array}{c}\text { Treatment / } \\
\text { Date }\end{array}$ & $\begin{array}{c}\% \text { of flowered } \\
\text { palms } 04 / 98 \text { - } \\
28 \text { months } \\
\end{array}$ & $\begin{array}{c}\% \text { of flowered } \\
\text { palms } 07 / 98- \\
31 \text { months } \\
\end{array}$ & $\begin{array}{c}\% \text { of flowered } \\
\text { palms 10/98 - } \\
34 \text { months } \\
\end{array}$ & $\begin{array}{c}\% \text { of flowered } \\
\text { palms 01/99 } \\
37 \text { months } \\
\end{array}$ \\
\hline N0 & 11 & 32 & 47 & 69 \\
\hline $\mathrm{N} 1$ & $26 * *$ & $53 * *$ & $65 * *$ & 80 \\
\hline $\mathrm{N} 2$ & $30 * *$ & $56 * *$ & $67 * *$ & 79 \\
\hline $\mathrm{ClO}$ & 19 & 41 & 56 & 74 \\
\hline $\mathrm{Cl1}$ & $25 * *$ & $52 * *$ & $64 * *$ & 78 \\
\hline
\end{tabular}

\begin{tabular}{|c|c|c|c|c|c|c|}
\hline$* *$ : significa & $\begin{array}{l}10 \text { : Flower } \\
1 \% * \text { : signi }\end{array}$ & $\begin{array}{l}\text { ring } \\
\text { iific }\end{array}$ & $\begin{array}{l}\text { haracters and } \\
\text { t at } 5 \%\end{array}$ & ut set observe & between treat & ents \\
\hline Treatment & $\begin{array}{l}\text { Nb spathes } \\
\text { emitted 04- }\end{array}$ & & $\begin{array}{r}\text { Nb bunch } \\
\text { set } /\end{array}$ & $\begin{array}{l}\text { with nut } \\
\text { lmm }\end{array}$ & $\mathrm{Nb}$ of $\mathrm{nu}$ & set /palm \\
\hline & 10/98 perioc & & $07 / 98$ - 10/98 & $10 / 98-01 / 99$ & $07 / 98$ - 10/98 & $10 / 98-01 / 99$ \\
\hline N0 & 2.70 & & 0.14 & 0.60 & 0.7 & 2.6 \\
\hline $\mathrm{N} 1$ & $5.01 *$ & $* *$ & $0.66 * *$ & $1.45 * *$ & $3.0 * *$ & $6.7 *$ \\
\hline $\mathrm{N} 2$ & $5.21 *$ & $* *$ & $0.88 \quad * *$ & $1.45 * *$ & $4.3 \quad * *$ & $7.4 \quad * *$ \\
\hline $\mathrm{Cl0}$ & 3.82 & & 0.46 & 1.00 & 2.1 & 4.6 \\
\hline Cl1 & $4.80 *$ & $* *$ & 0.66 & $1.33 * *$ & 3.3 & $6.6 *$ \\
\hline
\end{tabular}




\begin{tabular}{|c|c|c|c|c|c|c|c|c|c|c|c|c|c|c|}
\hline \multicolumn{15}{|c|}{\begin{tabular}{|l|} 
J.R. Mc Alpine et al (1975) \\
\end{tabular}} \\
\hline \multicolumn{2}{|c|}{ Station / month } & Jan & Feb & Mar & Apr & May & Jun & Jul & Aug & Sep & Oct & Nov & Dec & \\
\hline \multicolumn{15}{|c|}{ Port Moresby - N.C.D. } \\
\hline \multirow[t]{3}{*}{ Wind } & Direction (deg) & 342 & 344 & 342 & 61 & 133 & 142 & 144 & 148 & 145 & 147 & 107 & 351 & \\
\hline & Speed (knot) & 3 & 4 & 3 & 0 & 2 & 5 & 6 & 5 & 4 & 3 & 1 & 2 & \\
\hline & Rainfall (mm) & 169 & 221 & 191 & 167 & 51 & 40 & 20 & 34 & 40 & 40 & 69 & 156 & 1,197 \\
\hline \multicolumn{15}{|c|}{ Madang - Madang province } \\
\hline \multirow[t]{3}{*}{ Wind } & Direction (deg) & 259 & 265 & 269 & 265 & 248 & 263 & 356 & 41 & 93 & 78 & 261 & 258 & \\
\hline & Speed (knot) & 2 & 2 & 1 & 1 & 1 & 1 & 0 & 1 & 1 & 0 & 0 & 1 & \\
\hline & Rainfall (mm) & 359 & 292 & 344 & 443 & 337 & 209 & 166 & 128 & 144 & 301 & 387 & 379 & 3,518 \\
\hline \multicolumn{15}{|c|}{ Lae - Morobe province } \\
\hline \multirow[t]{3}{*}{ Wind } & Direction (deg) & 306 & 306 & 303 & 309 & 314 & 326 & 315 & 297 & 304 & 302 & 303 & 303 & \\
\hline & Speed (knot) & 7 & 7 & 6 & 4 & 2 & 2 & 1 & 1 & 1 & 2 & 3 & 4 & \\
\hline & Rainfall (mm) & 267 & 231 & 324 & 403 & 424 & 414 & 501 & 517 & 473 & 386 & 346 & 332 & 4,617 \\
\hline \multicolumn{15}{|c|}{ Rabaul - Morobe province } \\
\hline \multirow[t]{3}{*}{ Wind } & Direction (deg) & 306 & 302 & 305 & 125 & 124 & 126 & 129 & 128 & 131 & 131 & 132 & 261 & \\
\hline & Speed (knot) & 2 & 2 & 1 & 1 & 4 & 5 & 7 & 6 & 6 & 5 & 3 & 0 & \\
\hline & Rainfall (mm) & 230 & 244 & 256 & 209 & 129 & 114 & 104 & 103 & 94 & 118 & 173 & 238 & 2,003 \\
\hline \multicolumn{15}{|c|}{ Lorengau - Manus province } \\
\hline \multirow[t]{3}{*}{ Wind } & Direction (deg) & 307 & 304 & 303 & 276 & 135 & 134 & 141 & 143 & 150 & 146 & 247 & 281 & \\
\hline & Speed (knot) & 4 & 4 & 3 & 2 & 2 & 3 & 5 & 5 & 4 & 3 & 2 & 3 & \\
\hline & Rainfall (mm) & 270 & 260 & 305 & 287 & 215 & 308 & 335 & 291 & 257 & 230 & 240 & 311 & 3341 \\
\hline
\end{tabular}

